\title{
Some Effects of Gram-negative Bacterial Endotoxin and its Importance as a Contaminator of Biological Preparations
}

\author{
By Chahna R. Yagoda, Ann-Christin Bylund-Fellenius and Hans Kindahl
}

Pharmacia LEO Therapeutics AB, and Swedish University of Agricultural Sciences, Department of Obstetrics and Gynaecology, Uppsala, Sweden.

\begin{abstract}
Yagoda, C. R., A.-C. Bylund-Fellenius and H. Kindahl: Some effects of Gramnegative bacterial endotoxin and its importance as a contaminator of biological preparations. Acta vet. scand. 1990, 31, 193-206. - The purpose of this study was to establish a model which can be used to examine the biological response to Salmonella typhimurium endotoxin in both anaesthetized and unanaesthetized rabbits, and then compare this response to that of rabbits injected with an endotoxincontaminated biological preparation. The parameters used to evaluate the biological response included total white blood cell and differential counts, 15-ketodihydro- $\mathrm{PGF}_{2 a}$ concentration, and rectal temperature.

Unanaesthetized groups of rabbits received $1000,100,10$, or $1 \mathrm{ng} / \mathrm{kg}$ of the endotoxin via intravenous injection (i.v.); the anaesthetized group of rabbits received $100 \mathrm{ng} / \mathrm{kg}$ endotoxin i.v. (anaesthesia induced with Hypnorm ${ }^{\otimes}$ ). In addition, groups of rabbits were treated under anaesthesia with Pharmacia-Chiron's recombinant human $\mathrm{Cu} / \mathrm{Zn}$ superoxide dismutase (SOD) $(10 \mathrm{mg} / \mathrm{kg}$ body weight $=1.6$ endotoxin units $(\mathrm{EU}) / \mathrm{kg}$ ) or Grünenthal's bovine SOD (two doses: $10 \mathrm{mg} / \mathrm{kg}=400$ $\mathrm{EU} / \mathrm{kg}$, or $50 \mathrm{mg} / \mathrm{kg}=2000 \mathrm{EU} / \mathrm{kg}$ ).

Results demonstrated that at the lower doses of endotoxin $(10$ and $1 \mathrm{ng} / \mathrm{kg})$ and $\mathrm{r}$-hSOD $(10 \mathrm{mg} / \mathrm{kg})$, no leukopenia was observed. There was however a slight shift in the leukocyte population so that polymorphonucleocytes increased and monocytes decreased in number. Rabbits treated with higher doses of endotoxin $(1000$ and $100 \mathrm{ng} / \mathrm{kg}$ ) showed many of the common signs of endotoxemia, including leukopenia, increased prostaglandin metabolite levels, and increased body temperature, as did the rabbits treated with endotoxin-contaminated bSOD. There was a definite dose-dependency, with the higher dose of bSOD giving a more marked rise in all parameters. These findings indicate that use of this or other endotoxincontaminated biological preparations in live-animal experiments could produce erratic, and therefore unreliable, results.
\end{abstract}

prostaglandin; superoxide dismutase; white blood cells; rabbit.

\section{Introduction}

Endotoxins are currently the topic of intense research in many different fields. This interest is understandable considering the incredible spectrum of pathological activities that endotoxin has in the mammalian body (Fredriksson 1984a, Cort 1985, Daels et al. 1987, Morrison \& Ryan 1987). It has recent- ly been discovered that endotoxin, although previously thought to result only in pathological conditions due to its pro-inflammatory properties, can ironically also have some positive effects. It was found for example that endotoxin contamination of a catalase preparation used in a vascular permeability study was probably the factor 
which led to protective effects in induced airway edema in guinea pigs (Gordon et al. 1987). Prevention of inflammatory injury has also been shown by intra-peritoneal injection of endotoxin (Frank et al. 1978, Koizumi et al. 1985, Tejedor et al. 1986).

Endotoxin contamination is a problem in many commercially available protein preparations, a fact that can severely complicate the interpretation of pharmacological studies in light of the broad spectrum of biological effects reported for endotoxins. In addition to the development of better techniques for detection and elimination of endotoxins therefore further studies aimed at understanding the dose-effect relationship in vivo is warranted.

The toxic effects of endotoxin are multiple and varied. Endotoxin has been shown to be a strong pyrogen in many different species. The fever elicited by endotoxin administration tends to be biphasic after high endotoxin doses, and monophasic after low endotoxin doses (Skarnes et al. 1981). The pyrogenic effect of endotoxin appears to be mediated indirectly through stimulation of blood granulocytes causing release of endogenous pyrogens (interleukin 1). The pyrogens act on central thermoregulatory centers to cause fever (Milton 1982).

Endotoxin is also responsible for activation of the arachidonic acid cascade, leading to production of many different prostaglandins, thromboxanes, and leukotrienes. These substances act as important mediators for many of endotoxins' biological effects. For example, prostaglandin $F_{2 \alpha}$ release can lead to changes in reproductive function in both normally cycling and pregnant animals (Fredriksson 1984a, Cort 1985, Daels et al. 1987).

Endotoxin causes markedly rapid changes in both total leukocyte count and in the ratio between numbers of polymorphonucleocytes
(PMN) and monocytes (M). Within minutes of endotoxin administration the numbers of PMN begin to fall, reaching a minimum limit at about 30-60 min, depending on the dose administered and the animal tested (Fredriksson 1984a). This depression in $\mathrm{PMN}$ is later followed by an increase in total leukocyte count; an effect caused first by a margination of cells in the circulating pool, and then by a movement from the marginating pool out into the circulating pool again (MacGreggor 1977). Whether endotoxin acts directly on the bone marrow to cause increased release of new granulocytes, or whether this effect is secondary to the intense leukopenia is yet unknown.

The changes listed above are linked to many different pathological conditions which arise after bacterial infection or injection of an endotoxin contaminated preparation to an animal (Bito 1977, Zuckerman et al. 1979). Because of the multiple effects of endotoxin, difficulties arise when trying to qualify and quantify its biological activity. To further complicate matters, individual animals respond very differently to endotoxin. Severity and duration of response usually varies considerably. A subdued response may occur because of previous exposure to endotoxin. Tolerance has been shown to arise with repeated exposure to endotoxin (Lindberg et al. 1983). Whether this tolerance arises through anti-endotoxin activity of immunoglobulins of IgG and IgM classes, increased reticulo-endothelial-system inactivation of the endotoxin, and/or cell mediated immunity is yet unclear (Fredriksson 1984a). In a study with repeated injections of endotoxin to pigs it was shown that the clinical response declined, but the prostaglandin release was essentially the same after the first day (Yagoda et al. 1988). However, response to endotoxin frequently varies among individuals even when tolerance can 
be ruled out as an influencing factor. It is therefore difficult to establish a reliably repeatable dose-response curve for a given endotoxin.

The purpose of this project was to establish a model in the rabbit which could be used to measure the dose-effect relationship of Salmonella typhimurium endotoxin in both anaesthetized and unanaesthetized animals. This model could later be used to quantitatively as well as qualitatively evaluate the level of endotoxin contamination in commercial biological pharmaceutical preparations.

\section{Materials and methods Animals}

Forty-one New Zealand white male rabbits from 'Estuna smådjursfarm' were housed and fed according to Standard Operating Procedure. All rabbits weighed between 2.5 and $3.5 \mathrm{~kg}$ as isolation and catheterization of the caudal auricular artery is easier in rabbits of this size. The number of rabbits tested per day and the route of endotoxin administration varied between the rabbits first tested and the rabbits tested later when the model had been more completely worked out. For the purpose of this study all results from rabbits in a given dose group will be set together, with notations specifying the protocol used for each group of animals (Table 1). The general procedure was however as follows: unanaesthetized animals were first weighed and then placed in a relatively disturbance-free room which varied not more than $2^{\circ} \mathrm{C}$ from the room where they were normally housed. Rectal probes were inserted to approximately $5 \mathrm{~cm}$ - they were not however taped to the animals tail as this caused discomfort. Instead the probes were checked frequently during the course of the day to ensure that they had not been expulsed. The probes were left in for $30 \mathrm{~min}$
Table 1. Groups of animals and treatments received.

\begin{tabular}{llc}
\hline Treatment & Condition & Number \\
\hline Control (saline) & Unanaesthetized & 7 \\
Endotoxin & & \\
$1000 \mathrm{ng} / \mathrm{kg}$ & Unanaesthetized & 7 \\
$100 \mathrm{ng} / \mathrm{kg}$ & Unanaesthetized & 7 \\
$100 \mathrm{ng} / \mathrm{kg}$ & Anaesthetized & 6 \\
$10 \mathrm{ng} / \mathrm{kg}$ & Unanaesthetized & 3 \\
$1 \mathrm{ng} / \mathrm{kg}$ & Unanaesthetized & 2 \\
Superoxide & & \\
dismutase $(S O D)$ & & \\
r-hSOD $10 \mathrm{mg} / \mathrm{kg}$ & Anaesthetized & 3 \\
bSOD $10 \mathrm{mg} / \mathrm{kg}$ & Anaesthetized & 3 \\
bSOD 50 mg/kg & Anaesthetized & 3 \\
\hline
\end{tabular}

before the first temperature reading was recorded. If the base-line temperature was greater than $39^{\circ} \mathrm{C}$, or if the temperature varied by more than $1^{\circ} \mathrm{C}$ during the first 30 min then the animal was not used on that day.

The ear artery was catheterized under local anaesthesia (Xylocain ${ }^{\circledR}$ subcutaneously, approximately $1 \mathrm{ml}$ ) and the animal was allowed to sit undisturbed for $15 \mathrm{~min}$ before the first blood collection. Temperature was noted for all animals. General anaesthesia was attained using Hypnorm ${ }^{\circledR}$ intramuscularly at a dose of approximately $0.5 \mathrm{ml} / 30$ min. Larger rabbits occasionally required a little extra Hypnorm ${ }^{\circledR}$ to hold them in a totally anaesthetized state. If so, they were given $0.2 \mathrm{ml}$ extra when necessary. Anaesthetized animals were placed on heating pads set for $37^{\circ} \mathrm{C}$ in order to counteract the temperature sinking effects of Hypnorm ${ }^{\circledR}$ anaesthesia.

Blood was collected into heparinized tubes according to the following time schedule: $-15,0,10,30,60,90,120,180,240$, and $330 \mathrm{~min}$. The blood was then treated in the following manner: hematocrit was measured 
to check that Packed Cell Volume had not decreased by more than 25-30\%, the blood was mixed for at least $5 \mathrm{~min}$, after which 20 $\mu \mathrm{l}$ was pipetted into a tube containing $180 \mu \mathrm{l}$ of Turk's solution, the rest of the blood was centrifuged for $10 \mathrm{~min}$ and the plasma was pipetted off and frozen for later 15-keto-(13, 14)-dihydro-PGF $2 \alpha$ analysis using a radioimmunoassay as described by Granström \& Kindahl (1982a). The tube with Turk's solution was mixed for a minimum of $10 \mathrm{~min}$. This mixture was then set in a BürkerChamber and allowed to settle $5 \mathrm{~min}$. The number of polymorphonuclear cells (PMN) and mononuclear cells (M) in $32 \mathrm{~A}$ squares were counted. (Note: This number multiplied by $50 \times 10^{6}$ gives the number of cells/ 1 blood). All blood collections were done as calmly and quietly as possible so as not to excite the animals more than necessary.

\section{Treatments}

Four different doses of Salmonella typhimurium endotoxin were administered, 1000, 100, 10 and $1 \mathrm{ng} / \mathrm{kg}$ (see Fredriksson (1984b) for a description of the endotoxin preparation). Animals treated with recombinant human $\mathrm{Cu} / \mathrm{Zn}$-superoxide dismutase (r-hSOD, Pharmacia-Chiron, batch no: I 208707) received $10 \mathrm{mg} / \mathrm{kg}$, dissolved in saline. Endotoxin contents were determined by a Limulus Amoebocyte Lysate (LAL) test according to Friberger (1985) and expressed in endotoxin units (EU). This r-hSOD preparation contained $0.16 \mathrm{EU} / \mathrm{mg}$ protein. Animals that received highly endotoxin contaminated superoxide dismutase were treated with either $10 \mathrm{mg} / \mathrm{kg}$ or $50 \mathrm{mg} / \mathrm{kg}$ of bovine $\mathrm{Cu} / \mathrm{Zn}$-superoxide dismutase (bSOD), Grünenthal, batch no: JO56. This contained $40 \mathrm{EU} / \mathrm{mg}$ protein. The control animals received $1 \mathrm{ml}$ of saline. The saline was considered to be pyrogen free $(<0.12$ $\mathrm{EU} / \mathrm{ml}$ ). One nanogram of the Salmonella typhimurium endotoxin had an approximate activity of $10 \mathrm{EU}$ in the LAL-test. The animals were injected slowly with their respective treatments i.v. immediately after time 0 blood collection. Time at 0 was noted on each animal chart for later reference. The animals were killed using an excess of anaesthesia. The results are expressed as mean \pm standard deviation (SD).

\section{Results}

\section{Endotoxin treated and control rabbits}

Leukocyte numbers. Changes in numbers of circulating leukocytes proved to be a sensitive, if somewhat variable parameter. In control animals a slight increase in number of total leukocytes was seen (Fig. 1a). Leukopenia was induced rapidly after high dose endotoxin adminstration (Fig. 1a). In the $1000 \mathrm{ng} / \mathrm{kg}$ group, the total number of leukocytes decreased from base-line levels of $4.9 \pm 2.2 \times 10^{9}$ cells $/ 1$ blood to $3.1 \pm 1.5 \times$ $10^{9}$ cells $/ 1$ blood within $10 \mathrm{~min}$ of endotoxin administration. Total leukocyte numbers continued to drop for a full $240 \mathrm{~min}(1.3 \pm$ $0.6 \times 10^{9}$ cells $/$ blood), after which numbers began to increase towards base levels, reaching $3.6 \pm 2.1 \times 10^{9}$ cells $/ 1$ blood by 330 $\mathrm{min}$. This response was parallelled in both the anaesthetized and unanaesthetized groups of rabbits, who received $100 \mathrm{ng} / \mathrm{kg}$ endotoxin. The decrease in total leukocyte numbers in these groups was however neither as quickly induced nor as drastic. Anaesthetized rabbits had lower base-line levels of leukocytes, $3.7 \pm 0.9 \times 10^{9}$ cells/l blood. This level decreased slowly after $10 \mathrm{~min}$ for a period of $120 \mathrm{~min}$, when there were an average of $1.3 \pm 0.6 \times 10^{9}$ cells $/ 1$ blood Thereafter leukocyte levels increased. At $330 \mathrm{~min}$, leukocyte concentration was $5.1 \pm$ $1.6 \times 10^{9}$ cells $/ 1$ blood. The unanaesthetized group of rabbits treated with $100 \mathrm{ng} / \mathrm{kg}$ endotoxin also showed decreases in leuko- 

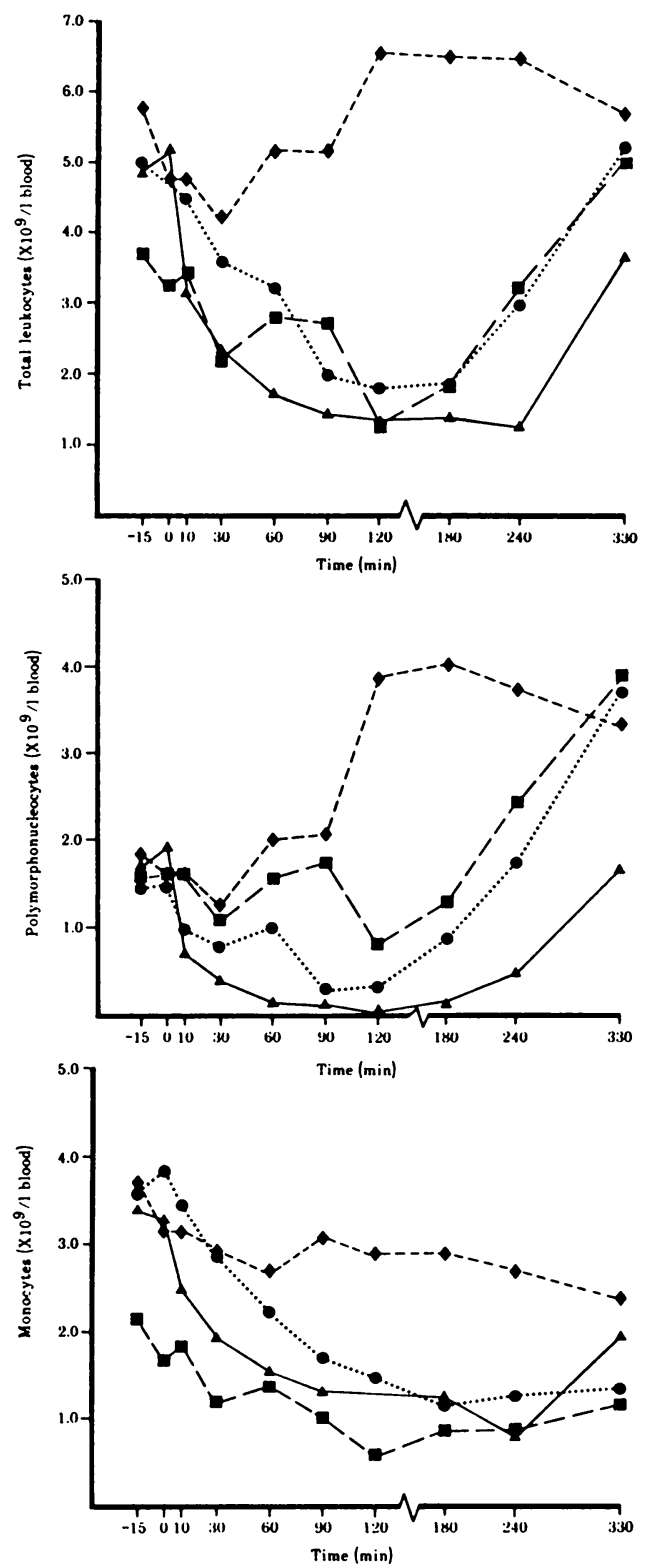

Figure 1. Changes in total leukocyte (a), polymorphonucleocyte (b), and monocyte (c) numbers over time in groups of rabbits having received one of the following treatments: endotoxin of Salmonella typhimurium at $1000(\Delta)$ or $100(\bullet) \mathrm{ng} / \mathrm{kg}$, $100 \mathrm{ng} / \mathrm{kg}$ while under Hypnorm anaesthesia $(\square)$, or $1 \mathrm{ml}$ saline $(\bullet)$. (Time of injection is at time zero).

cyte numbers starting approximately $10 \mathrm{~min}$ after endotoxin administration. Numbers decreased from a base-line of $5.0 \pm 2.6 \times 10^{9}$ cells/l blood to $1.8 \pm 1.1 \times 10^{9}$ cells $/ \mathrm{l}$ blood at $120 \mathrm{~min}$, after which levels increased, reaching $5.2 \pm 3.4 \times 10^{9}$ cells $/ 1$ blood at 330 $\min$.

If one divides the leukocyte population into 2 subgroups, polymorphonuclear (PMN) and mononuclear cells (M), it becomes clear that those in the former group, i.e., pseudoneutrophils, basophils, and eosinophils, were mainly responsible for the decrease in white blood cell numbers which occurred shortly after endotoxin administration in the 1000 and $100 \mathrm{ng} / \mathrm{kg}$ groups (Fig. 1b). The group treated with $1000 \mathrm{ng} / \mathrm{kg}$ endotoxin for example showed decreases in PMN from a base-line of $1.7 \pm 1.1 \times 10^{9}$ cells $/ 1$ blood to a minimum of $0.1 \pm 0.1 \times 10^{9}$ cells $/ 1$ blood at $120 \mathrm{~min}$. Both the unanaesthetized and anaesthetized groups treated with $100 \mathrm{ng} / \mathrm{kg}$ showed an initial decrease from base-line PMN numbers (which were $1.4 \pm 1.1 \times 10^{9}$ cells $/ \mathrm{l}$ blood and $1.5 \pm 0.7 \times 10^{9}$ cells $/ 1$ blood respectively) shortly after endotoxin administration followed by a slight increase in $P M N$ which peaked at $60 \mathrm{~min}(1.0 \pm 1.1$ $\times 10^{9}$ cells $/ 1$ blood $)$ and $90 \mathrm{~min}(1.7 \pm 1.0 \times$ $10^{9}$ cells/l blood) respectively. Polymorphonuclear cell numbers in the 2 groups then dropped rapidly to minimums of $0.3 \pm 0.3$ $\times 10^{9}$ cells $/ 1$ blood and $0.8 \pm 0.5 \times 10^{9}$ cells $/ \mathrm{l}$ blood at $90 \mathrm{~min}$ and $120 \mathrm{~min}$ respectively, and finally rose to values exceeding the original base-line levels $\left(3.7 \pm 2.9 \times 10^{9}\right.$ cells $/ 1$ blood and $3.9 \pm 1.6 \times 10^{9}$ cells $/ 1$ blood respectively). All 3 groups treated with endotoxin contrasted well with the control group. Base-line PMN levels in this group started at $1.8 \pm 1.5 \times 10^{9}$ cells $/ 1$ blood, decreased slightly after $10 \mathrm{~min}$, but then began to rise, reaching a peak level at $180 \mathrm{~min}\left(4.1 \pm 1.6 \times 10^{9}\right.$ cells $/ 1$ blood $)$. 

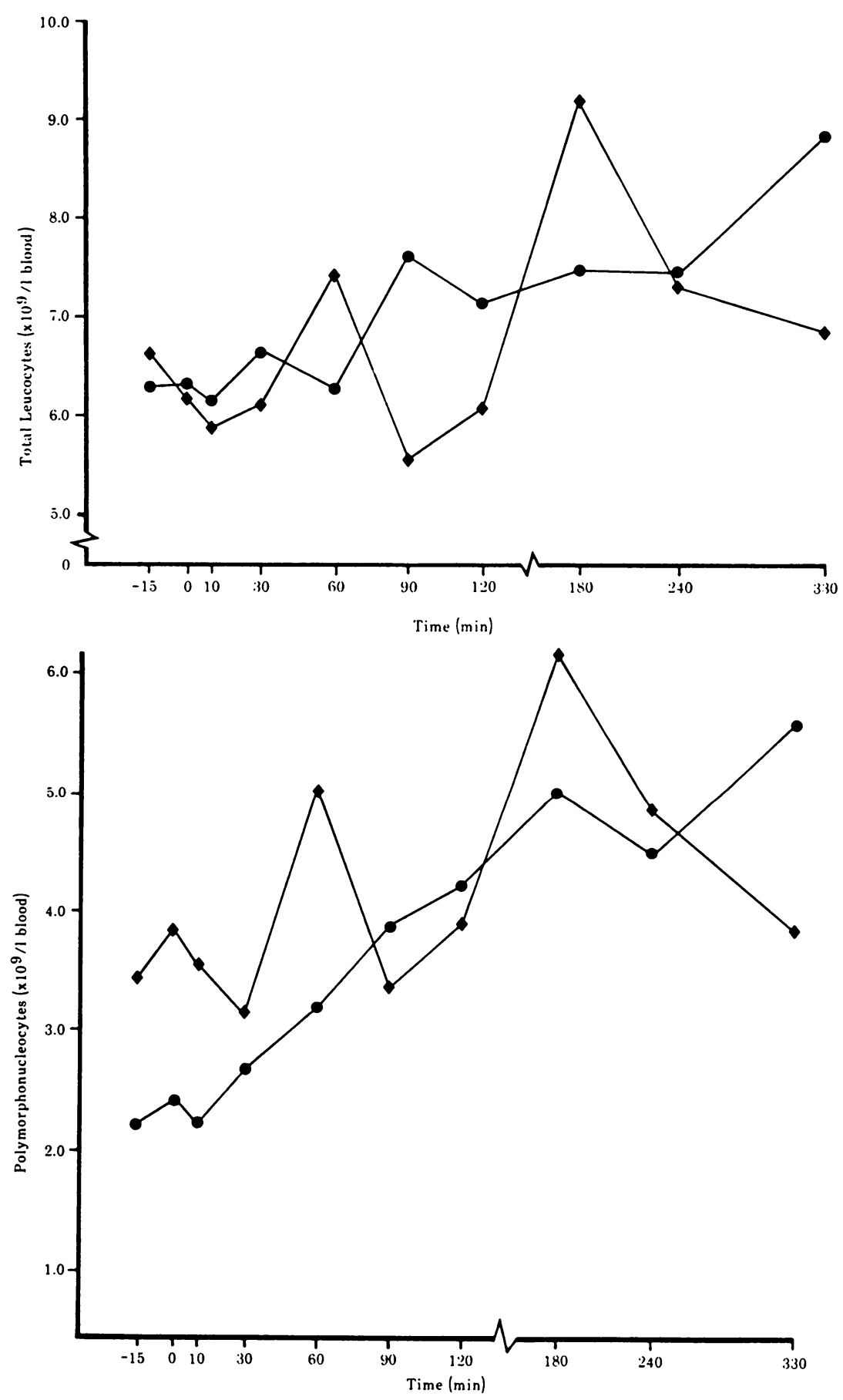


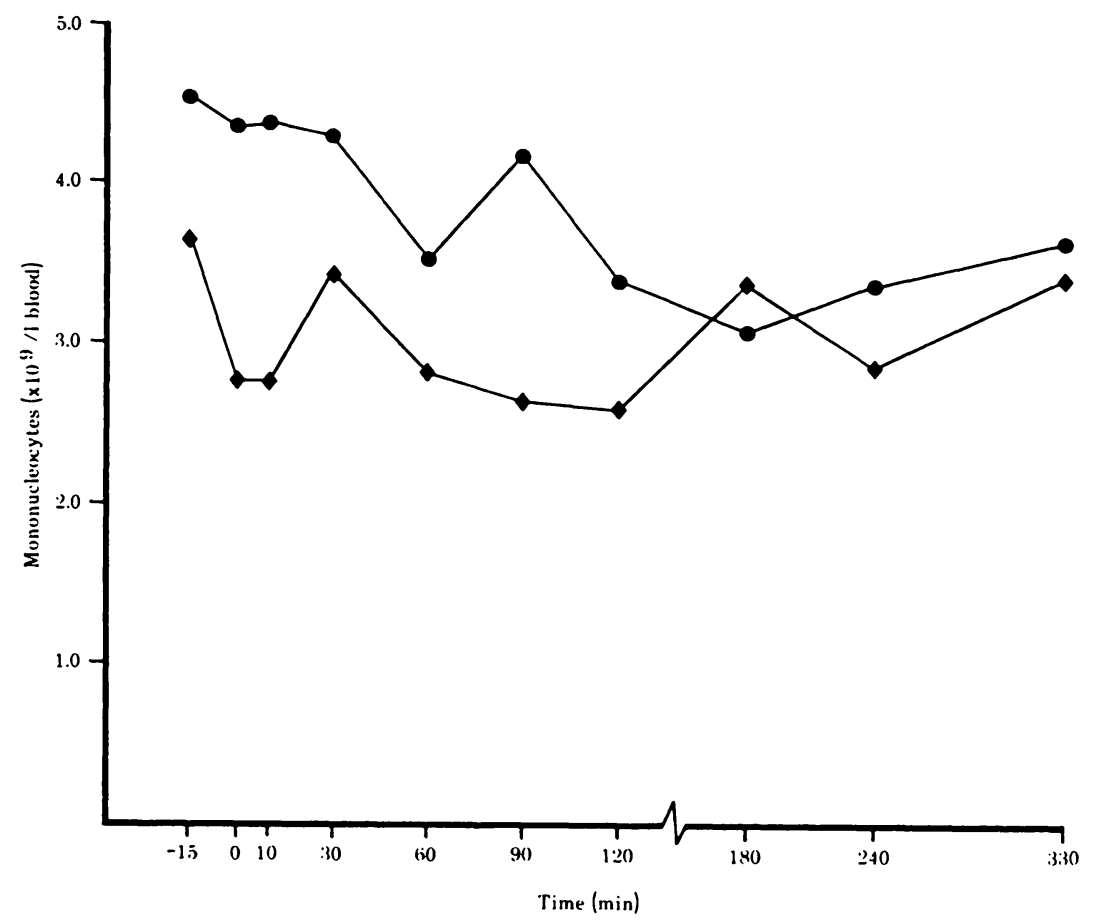

Figure 2. Changes in total leukocyte (a), polymorphonucleocyte (b), and monocyte (c) numbers over time in rabbits having received one of the following low doses of S. typhimurium endotoxin: $10(\diamond)$ or $1(\bullet)$ $\mathrm{ng} / \mathrm{kg}$. (Time of injection is at time zero).

Levels finally sank to a final value of $3.3 \pm$ $1.4 \times 10^{9}$ cells $/ 1$ blood at $330 \mathrm{~min}$.

The mononucleocyte $(\mathrm{M})$ cell population, composed of both monocytes and lymphocytes, also decreased in number after high dose endotoxin administration (Fig. 1c). Base-line levels in the $1000 \mathrm{ng} / \mathrm{kg}$ group were $3.4 \pm 1.5 \times 10^{9}$ cells $/ 1$ blood at -15 min. After endotoxin administration numbers fell steadily for $240 \mathrm{~min}$, reaching a minimum of $0.8 \pm 0.4 \times 10^{9}$ cells $/ 1$ blood. Thereafter, numbers began to increase, but reached only $2.0 \pm 2.3 \times 10^{9}$ cells $/ 1$ blood by $330 \mathrm{~min}$. The response of the unanaesthetized group treated with $100 \mathrm{ng} / \mathrm{kg}$ was very similar: base-line mononuclear cell numbers equalled $3.6 \pm 1.7 \times 10^{9}$ cells $/ 1$ blood at $-15 \mathrm{~min}$, fell to a minimum of 1.1 $\pm 0.5 \times 10^{9}$ cells $/ 1$ blood at $180 \mathrm{~min}$, and then began to increase, reaching $1.4 \pm 0.7 \times$ $10^{9}$ cells $/ 1$ blood at $330 \mathrm{~min}$. Although the anaesthetized group of rabbits (also 100 $\mathrm{ng} / \mathrm{kg}$ ) began with lower $\mathrm{M}$ base-line levels $\left(2.2 \pm 0.4 \times 10^{9}\right.$ cells $/ 1$ blood $)$, the response was parallel to that of the other 2 endotoxintreated groups. Mononucleocyte numbers in the control group were more constant, with a base-line of $3.7 \pm 1.8 \times 10^{9}$ cells $/ \mathrm{l}$ blood, which decreased slowly to $2.4 \pm 0.8 \times 10^{9}$ cells $/ 1$ blood at $330 \mathrm{~min}$.

Neither the $10 \mathrm{ng} / \mathrm{kg}$ nor the $1 \mathrm{ng} / \mathrm{kg}$ group of rabbits showed any large or direct response to the administration of endotoxin (Fig. 2a). Values for the total leukocytes rose steadily, albeit unevenly, from base-lines of $6.6 \pm 2.5$ and $6.3 \times 10^{9}$ cells $/ 1$ blood to 
peaks of $9.2 \pm 1.7$ and $8.8 \times 10^{9}$ cells $/ 1$ blood at 180 and $330 \mathrm{~min}$ respectively. Within both groups this change was brought about by increasing numbers of PMN combined with a decreasing numbers of monocytes (Figs. $2 b$ and 2c). The increase in PMN was quite large for the $1 \mathrm{ng} / \mathrm{kg}$ treated group, which had a final value $(330 \mathrm{~min})$ of $5.7 \times 10^{9}$ cells $/ 1$ blood, as compared to the base-line of $2.2 \times 10^{9}$ cells $/ 1$ blood.

Temperature. The pyrogenicity of endotoxin, measured only in unanaesthetized rabbits, was confirmed in this model. Rabbits receiving $1000 \mathrm{ng} / \mathrm{kg}$ had a biphasic fever rising from a base line of $38.7 \pm 0.5^{\circ} \mathrm{C}$ to a temperature of $39.3 \pm 0.5^{\circ} \mathrm{C}$ at $240 \mathrm{~min}$ (Fig. 3). This response yielded an area of $13,530 \mathrm{~mm}^{2}$ under the curve, contrasted with $11,173 \mathrm{~mm}^{2}$ for the unanaesthetized rabbits $(100 \mathrm{ng} / \mathrm{kg})$ and $2,333 \mathrm{~mm}^{2}$ for the control rabbits. Endotoxin at $100 \mathrm{ng} / \mathrm{kg}$ did not seem to lead to a biphasic fever, but instead a monophasic response. Control rabbits remained fairly close to base-line temperature under the 330 min period.

Body temperature of animals in both the 10 $\mathrm{ng} / \mathrm{kg}$ and $1 \mathrm{ng} / \mathrm{kg}$ group was in essence con-

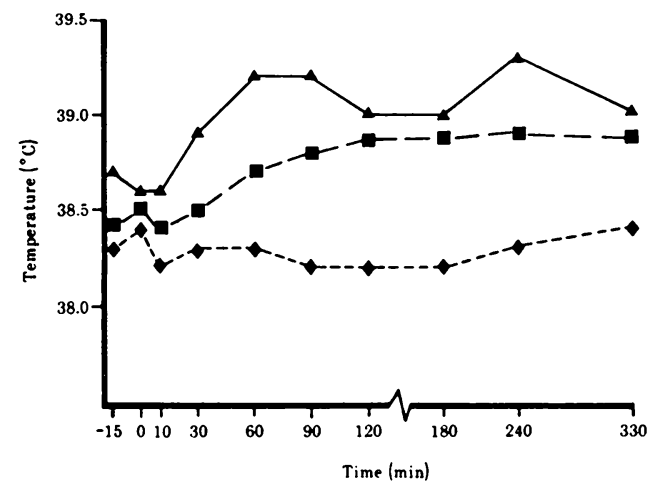

Figure 3. Changes in body temperature over time in unanaesthetized animals treated with: $1000(\Delta)$ or $100(\bullet) \mathrm{ng} / \mathrm{kg}$ S. typhimurium endotoxin, or $1 \mathrm{ml}$ saline $(\bullet)$. (Time of injection is at time zero). stant, with no significant rise or fall under the duration of the $330 \mathrm{~min}$.

15-Ketodihydro-PGF $2 \alpha$. The concentration of 15-ketodihydro-PGF ${ }_{2 \alpha}$ in the plasma of rabbits treated with saline was fairly stea$\mathrm{dy}$, remaining close to the base-line level of $236 \pm 109 \mathrm{pmol} / \mathrm{l}$ for the entire $330 \mathrm{~min}$ (Fig. 4a). 15-Ketodihydro-PGF $2 \alpha$ concentration in the $1000 \mathrm{ng} / \mathrm{kg}$ and $100 \mathrm{ng} / \mathrm{kg}$ groups increased drastically after endotoxin administration. Anaesthetized animals treated with $100 \mathrm{ng} / \mathrm{kg}$ started with a high base-line level of 15-ketodihydro-PGF $2 \alpha(660 \pm 545$ pmol/l) compared with unanaesthetized animals receiving the same dose $(284 \pm$ $141 \mathrm{pmol} / \mathrm{l})$ and animals treated with 1000 $\mathrm{ng} / \mathrm{kg}$ endotoxin $(342 \pm 408 \mathrm{pmol} / \mathrm{l})$. 15-Ketodihydro- $\mathrm{PGF}_{2 \alpha}$ levels in the anaesthetized group $(100 \mathrm{ng} / \mathrm{kg})$ were high at 0 $\min (848 \pm 641 \mathrm{pmol} / \mathrm{l})$. From this elevated level 15-ketodihydro-PGF $\mathrm{PF}_{2 \alpha}$ increased reaching a maximum value of $1254 \pm 566$ $\mathrm{pmol} / \mathrm{l}$ at $240 \mathrm{~min}$. The responses of the unanaesthetized group (100 ng/ $\mathrm{kg}$ ) and 1000 $\mathrm{ng} / \mathrm{kg}$ group were fairly similar, with both exhibiting an increase in 15-ketodihydro$\mathrm{PGF}_{2 \alpha}$ concentration. Peak levels in the unanaesthetized group (330 $\mathrm{min})$ equalled $1331 \pm 414 \mathrm{pmol} / \mathrm{l}$, as compared with 1664 $\pm 951 \mathrm{pmol} / \mathrm{l}$ for the $1000 \mathrm{ng} / \mathrm{kg}$ dose group. Note that although these standard deviations were large, this depended on a wide range in individual base-line values, rather than a difference in response to the endotoxin periods. In other words, the graphs of individual rabbits parallelled each other, although they began at different points.

The groups of rabbits treated with $10 \mathrm{ng} / \mathrm{kg}$ and $1 \mathrm{ng} / \mathrm{kg}$ endotoxin did not show any significant changes in 15-ketodihydro- PGF $_{2 \alpha}$ concentration over the $330 \mathrm{~min}$ period (Fig. $4 b)$. 

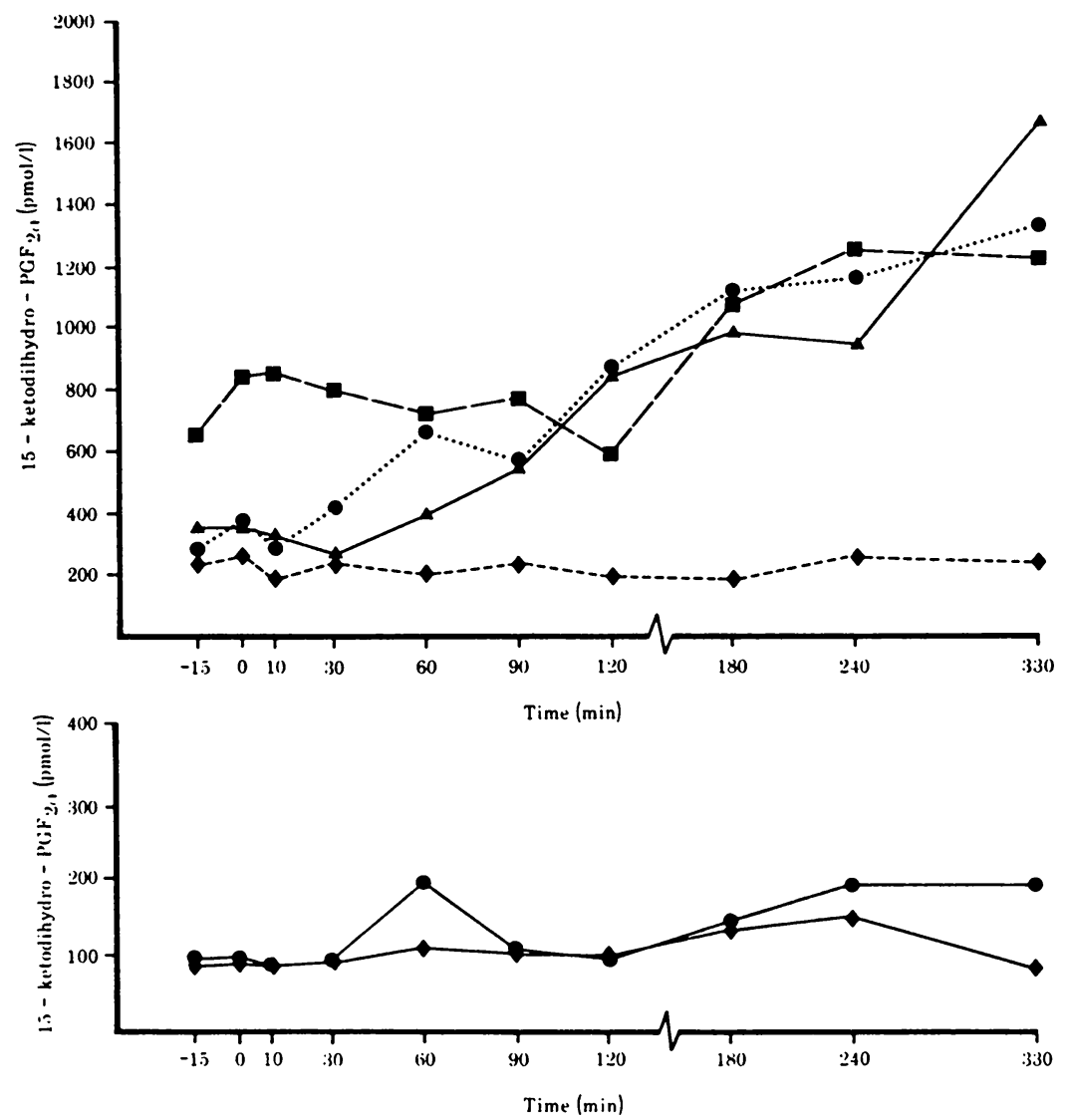

Figure 4. Peripheral plasma levels of 15-ketodihydro-PGF $2 a$ in groups of rabbits having received one of the following treatments: (a) S. typhimurium at 1000 (৫) or $100(\bullet) \mathrm{ng} / \mathrm{kg}, 100 \mathrm{ng} / \mathrm{kg}$ while under Hypnorm anaesthesia $(\square)$, or $1 \mathrm{ml}$ saline $(\bullet)$; (b) S. typhimurium at $10(\bullet)$ or $1(\bullet) \mathrm{ng} / \mathrm{kg}$. (Time of injection is at time zero).

$r-h S O D$ and endotoxin contaminated bSOD treated rabbits

Leukocyte numbers. The group of rabbits treated with dismutase had on a whole a lower base-line number of white blood cells (WBC) than the other groups of rabbits. Rabbits treated with r-hSOD (Fig. 5a) (baseline at $-15 \mathrm{~min}$ equal to $2.1 \pm 0.6 \times 10^{9}$ cells/l blood) exhibited a response similar to that seen in control rabbits, i.e., a trend to increasing numbers with a peak at approx- imately $120 \mathrm{~min}\left(5.1 \pm 2.8 \times 10^{9}\right.$ cells $/ 1$ blood). The ratio between PMN and $\mathrm{M}$ cells was also similar to that of control animals: increasing PMN numbers were responsible for the increase in WBC over time (Fig. 5b). In r-hSOD treated animals, however, $M$ levels were fairly constant (Fig. 5c), whereas in control animals $M$ decreased slightly in number (c.f. Fig. 1c).

The two groups $(10 \mathrm{mg} / \mathrm{kg}$ and $50 \mathrm{mg} / \mathrm{kg}$ ) treated with the endotoxin contaminated 


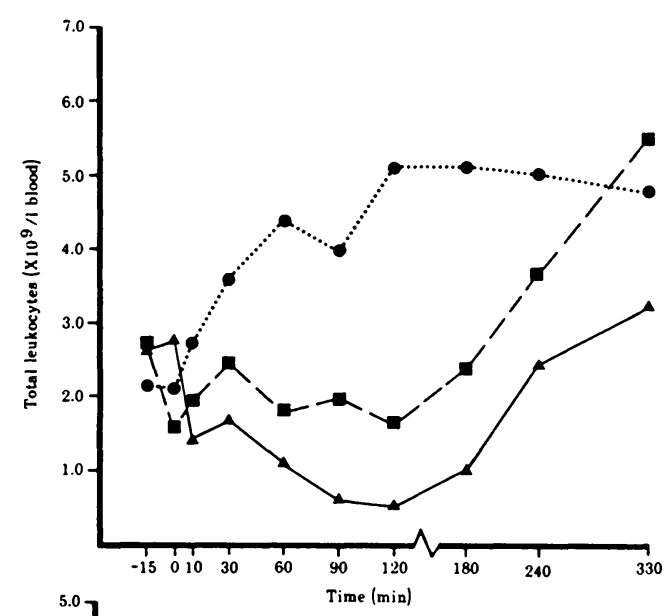

bSOD showed responses typical for endotoxin treated animals (Fig. 5a). Total leukocyte number decreased from base-line levels $\left(2.7 \pm 0.7 \times 10^{9}\right.$ and $2.6 \pm 0.6 \times 10^{9}$ cells $/ 1$ blood respectively). Thereafter WBC numbers increased to final values of $5.6 \pm 1.3$ and $3.2 \pm 2.1 \times 10^{9}$ cells $/ \mathrm{l}$ blood, respectively.

Polymorphonuclear cell numbers in both the $10 \mathrm{mg} / \mathrm{kg}$ and $50 \mathrm{mg} / \mathrm{kg}$ group decreased from base-line levels $(1.2 \pm 0.1$ and $1.3 \pm$ $0.4 \times 10^{9}$ cells $/ 1$ blood, respectively) after bSOD injection (Fig. 5b). Minimum PMN numbers occurred at $120 \mathrm{~min}(1.1 \pm 0.2 \times$ $10^{9}$ cells $/ 1$ blood $)$ and $90 \mathrm{~min}(0.1 \pm 0.1 \times$ $10^{9}$ cells/l blood), respectively. Polymorphonucleocyte numbers rose thereafter to levels exceeding base-line levels; $330 \mathrm{~min}$ posttreatment, rabbits treated with $10 \mathrm{mg} / \mathrm{kg}$ bSOD had $4.2 \pm 0.9 \times 10^{9}$ cells $/ 1$ blood whereas rabbits treated with $50 \mathrm{mg} / \mathrm{kg}$ bSOD had $2.4 \pm 1.8 \times 10^{9}$ cells $/ 1$ blood.

Mononuclear cell numbers in both the 10 $\mathrm{mg} / \mathrm{kg}$ and $50 \mathrm{mg} / \mathrm{kg}$ bSOD group decreased slightly and gradually after treatment administration (base-line levels were equal to $1.6 \pm 0.8$ and $1.3 \pm 0.3 \times 10^{9}$ cells $/ 1$ blood), reaching and remaining at minimum levels between 60 and $240 \mathrm{~min}$. Thereafter levels increased towards base-line levels (Fig. 5c).

15 -Ketodihydro-PGF $2 \alpha$. Plasma 15-ketodihydro-PGF $F_{2 a}$ levels were similar for the $\mathrm{r}$-hSOD and bSOD $(10 \mathrm{mg} / \mathrm{kg})$ treated groups; base-lines in these groups were 149 \pm 18 and $232 \pm 57 \mathrm{pmol} / \mathrm{l}$ (Fig. 6). These levels remained fairly constant for the first $120 \mathrm{~min}$ after treatment administration. Thereafter the 15-ketodihydro-PGF $2 \alpha$ metabolite increased in concentration, reaching $496 \pm 129$ and $662 \pm 311 \mathrm{pmol} / \mathrm{l}$ at $330 \mathrm{~min}$. The group treated with $50 \mathrm{mg} / \mathrm{kg}$ of bSOD had a very different response. Levels of the 15-ketodihydro-PGF $2 \alpha$ metabolite rose steadily from a base-line of $294 \pm 89$ 


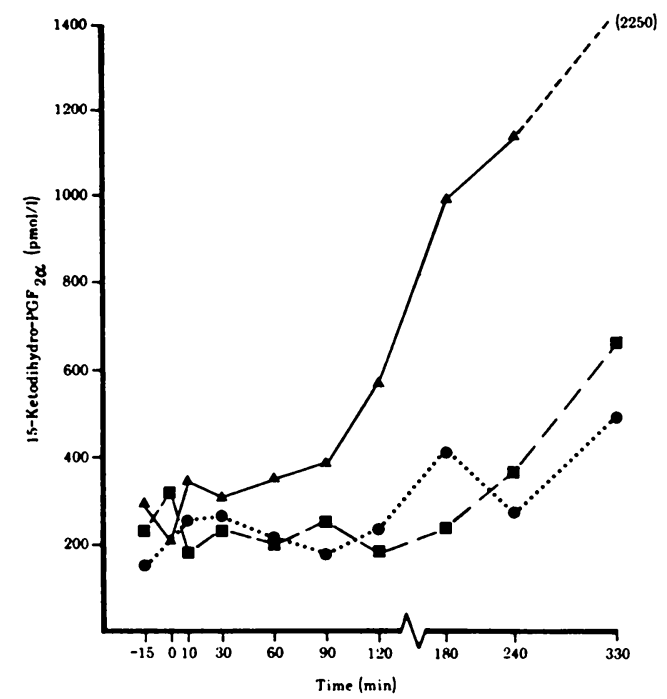

Figure 6. Peripheral plasma levels of 15-ketodihydro-PGF $2 \alpha$ in groups of rabbits having received one of the following treatments: 10 $\mathrm{mg} / \mathrm{kg} \mathrm{r}$-hSOD (๑), $10(\square)$ or $50(\Delta) \mathrm{mg} / \mathrm{kg}$ bSOD.

(Time of injection is at time zero).

$\mathrm{pmol} / \mathrm{l}$ to a maximum of approximately $2250 \pm 356 \mathrm{pmol} / \mathrm{l}$ at $330 \mathrm{~min}$.

\section{Discussion}

The common denominator in all the groups of rabbits was the incredible variability of response. It was therefore difficult to attain our primary goal, that of establishing a repeatable endotoxin dose-biological effect curve. Despite the fact, however, that our results did not give a clear dose-effect relation they demonstrated that endotoxin-contaminated pharmaceutical preparations can evoke the common symptoms of endotoxemia.

The effects of endotoxin administration in the rabbit were as expected: total white blood cell count decreased, temperature rose, and plasma concentration of the main prostaglandin metabolite, 15-ketodihydro$\mathrm{PGF}_{2 \alpha}$, increased. Of the parameters examined however, the one which yielded the most interesting result was 15 -ketodihydroPGF $_{2 a}$. Rabbits do not appear to exhibit the dramatic dose-dependent increase in plasma metabolite levels which is typical in almost every other species of animal examined (Fredriksson 1984, Daels et al. 1987). Instead we found a fairly slow increase in the plasma concentration of 15-ketodihydroPGF $_{2 \alpha}$ beginning approximately $30-60 \mathrm{~min}$ after endotoxin administration and continuing for the entire $330 \mathrm{~min}$ of the experiment. One possible reason that rabbits differ from other species might be that it is difficult to obtain a reliable measure of the prostaglandin profile due to the rapid metabolism seen in this species (Granström \& Kindahl 1982b). Granström \& Kindahl (1982b) noted that accurate measurement of prostaglandin production in the rabbit may be difficult for just this reason, and suggested instead use of a measurement system based on prostaglandin metabolite levels in the urine. The metabolic rate alone cannot account for the entirely different pattern of prostaglandin synthesis, however, as absolutely no peak in production was observed despite frequent blood sampling. The rabbit, although extremely sensitive to endotoxin, does therefore not seem to be the ideal animal to use in this particular type of experiment.

Leukocyte number in the venous blood decreased after administration of Salmonella typhimurium endotoxin and endotoxin-contaminated bSOD. These decreases did not appear to be significantly different between the groups, i.e. although on average the highest dose $(1000 \mathrm{ng} / \mathrm{kg})$ produced a greater and more sustained leukopenia, this difference was not statistically significant due to the great individual variation. The large decreases in white blood cell numbers were due mainly to decrease in PMN numbers. Endotoxin has been shown to have a dosedependent effect on the PMN cell popula- 
tion. In larger doses endotoxin stimulates release of the superoxide anion and lysosyme from PMN (Guthrie et al. 1984).

Two groups of rabbits were treated with very low doses of LPS, $10 \mathrm{ng} / \mathrm{kg}$ and $1 \mathrm{ng} / \mathrm{kg}$ respectively. The findings from these groups are presented here despite the small number of animals per group, and the therefore variable results, because these results echo those that the authors have seen in sheep treated with especially low doses of endotoxin ( $\mathrm{Ya}$ goda et al. 1990). The only parameters in which any great changes were seen were the total number of leukocytes, and the ratio between PMN and monocytes. In both groups the total number of leukocytes increased over base-line values. There was no tendency towards the leukopenia which was observed in the other groups treated with higher doses of endotoxin or contaminated bSOD. The curves of total leukocyte number over time for these low-dose endotoxin groups are quite similar, in fact, to the control and r-hSOD $(10 \mathrm{mg} / \mathrm{kg})$ groups. In addition to the rise in leukocyte number, the ratio of PMN:M increased over time in both the $10 \mathrm{ng} / \mathrm{kg}$ and $1 \mathrm{ng} / \mathrm{kg}$ groups. This shift in cell population has also been observed in sheep treated with low doses of Salmonella typhimurium (Yagoda et al. 1990), and in pigs treated daily with this endotoxin at a high dose over a 5-day-period (Yagoda et al. 1988). There most likely exists a threshold level over which animals respond to a given dose of endotoxin with a leukopenia and a decrease in both PMN and M, and under which they respond with a slight leukocytosis and an increased ratio in PMN:M. The mechanism by which this threshold arises, and what significance it has, are unclear.

The rabbits in the low-dose-endotoxin groups did not show a change in 15-ketodihydro- $\mathrm{PGF}_{2 \alpha}$ in response to endotoxin administration.
Endotoxin also causes, via stimulation of monocytes and macrophages, a release of monokines such as interleukin-1 and tumour necrosis factor. This increases the adherence of PMN to endothelial cell layers, and thus enhances cell migration out of the circulating pool into the marginated pool (Bevilacqua et al. 1985, Gamble et al. 1985). In smaller doses however endotoxin may both decrease PMN sensitivity to chemotactic factors and phagocytizing ability (Haslett et al. 1985).

The fact that we could not clearly distinguish this dose-dependence is not surprising - the parameters which one can measure in vivo are not as sensitive as those one can measure in vitro. Some dose-dependency was however visible in the groups treated with SOD.

The group treated with r-hSOD (1.6 endotoxin units (EU) $/ \mathrm{kg}$ body weight) had a 15-ketodihydro-PGF ${ }_{2 \alpha}$ response similar to the group treated with $10 \mathrm{mg} / \mathrm{kg}$ bSOD $(400$ $\mathrm{EU} / \mathrm{kg}$ body weight). The group treated with $50 \mathrm{mg} / \mathrm{kg}$ bSOD (2000 EU/ $\mathrm{kg}$ body weight) on the other hand showed a much greater increase in the prostaglandin metabolite level. This increase was similar in magnitude, although slightly later in occurrence, to that of groups treated with $1000 \mathrm{ng} / \mathrm{kg}$ and $100 \mathrm{ng} / \mathrm{kg}$ of the Salmonella typhimurium entotoxin. Interestingly, the dosedependency of the leukocyte cell population was such that the response of animals treated with $\mathrm{r}$-hSOD parallelled that of the control group, whereas the $10 \mathrm{mg} / \mathrm{kg}$ and 50 $\mathrm{mg} / \mathrm{kg}$ treated groups were similar.

Temperature was examined as a parameter only in the unanaesthetized animals. An increase in temperature was apparent after endotoxin administration. The graph of rabbits treated with $1000 \mathrm{ng} / \mathrm{kg}$ endotoxin had an area under the curve approximately 8 times greater than that of the control group. 
Area under the curve of those treated with $100 \mathrm{ng} / \mathrm{kg}$ endotoxin was approximately 6.6 times greater than that of control animals. However, the variation within the groups was so great that no significant differences between the 2 endotoxin groups can be reported.

Body temperature is always a difficult parameter to measure accurately, especially in an animal such as the rabbit, which is so easily frightened by disturbances in everyday routine. Perhaps if a better system for measurement of temperature could be devised, statistically significant differences in response to the 2 doses of endotoxin would emerge.

In this experiment it was shown that 2 different bSOD preparations contained sufficient amounts of endotoxin to induce endotoxemia. Unfortunately, many commercially available preparations are contaminated with endotoxins to a similar degree. The present findings demonstrate that the potent biological effects of endotoxin can therefore seriously interfere with the interpretation of pharmacological studies.

\section{Acknowledgements}

The authors give special thanks to Eva Jonsson and Catharina Wollert at Pharmacia LEO Therapeutics AB, Margareta Svensson, and Professor Lars-Erik Edqvist and his staff at the Department of Clinical Chemistry, Swedish University of Agricultural Sciences for all of their valuable help so generously given during this experiment.

This study was supported by grants from Pharmacia LEO Therapeutics AB and the Swedish Council for Forestry and Agricultural Research.

\section{References}

Bito LZ: Inflammatory effects of endotoxin like contaminants in commonly used protein preparations. Science 1977, 196, 83-85.

Bevilacqua MP, Pober JS, Wheeler ME, Cotran $R S$, Gimborne MA: Interleukin-1 acts on cultured human vascular endothelium to in- crease adhesion of polymorphonuclear leukocytes, monocytes, and related cell lines. J. clin. Invest. 1985, 76, 2003-2011.

Cort $N$ : Clinical and endocrine effects of oxytocin analogue and a bacterial endotoxin on reproduction in the sow. College of Veterinary Medicine, Swedish University of Agricultural Sciences, Ph.D. thesis, Uppsala, Sweden 1985.

Daels $P$, Starr $M$, Kindahl $H$, Fredriksson $G$, Hughes JP, Stabenfeldt GH: Effect of Salmonella typhimurium endotoxin on $\mathrm{PGF}_{2 \alpha}$ release and fetal death in the mare. J. Reprod. Fert. (Suppl. 35) 1987, 35, 485-492.

Frank L, Iam J, Roberts RJ: The role of endotoxin in protection of adult rats from high oxygen lung toxicity. J. clin. Invest. 1978, 61, 269-275.

Fredriksson G: Prostaglandins, endotoxins, and uterine bacteriology in reproduction of the doe and cow. College of Veterinary Medicine, Swedish University of Agricultural Sciences, Ph.D. thesis, Uppsala, Sweden 1984a.

Fredriksson $G$ : Some reproductive and clinical aspects of endotoxins in cows with special emphasis on the role of prostaglandins. Acta vet. scand. 1984b, 25, 365-377.

Friberger $P$ : The design of a reliable endotoxin test. In: Bacterial endotoxins: Structure, biomedical significance, and detection with the Limulus Amoebocyte Lysate test. Eds. ten Cates JW, Büller H, Stark A and Levine Y. Alan R Liss Inc., NY 1985, 139-149.

Gamble JR, Harlan JM, Klebanoff SJ, Vadas $M A$ : Stimulation of the adherence of neutrophils to umbilical vein endothelium by human recombinant tumour necrosis factor. Proc. Natl. Acad. Sci. 1985, 162, 1634.

Gordon T, Milligan SA, Levin J, Thompson JE, Fine JM, Sheppard D: Apparent effect of catalase on airway edema in guinea pigs Role of endotoxin contamination. Amer. Rev. respir. Dis. 1987, 135, 854-859.

Granström E, Kindahl H: Radioimmunoassay of the major plasma metabolite of $\mathrm{PGF}_{2 \alpha}, 15-$ keto-13,14-dihydro-PGF $2 \alpha$. Methods Enzymol. 1982a, 86, 320-339. 
Granström E, Kindahl $H$ : Species differences in circulating prostaglandin metabolites: Relevance for the assay of prostaglandin release. Biochim. Biophys. Acta 1982b, 713, 555-569.

Guthrie LA, McPhail LC, Henson PM, Johnston $R B$ : Priming of neutrophils for enhanced release of oxygen metabolites by bacterial lipopolysaccharides. J. exp. Med. 1984, 160, 1656 -1671 .

Haslett C, Guthrie LA, Kopianiak MM, Johnston $R B J r$, Henson PM: Modulation of multiple neutrophil functions by preparative methods or trace concentrations of bacterial lipopolysaccharides. Amer. J. Path. 1985, 119, 101 -110 .

Koizumi M, Frank L, Massaro D: Mitogenic effect of endotoxin on lung and tolerance of rats to hyperoxia. J. appl. Physiol. 1985, 59. 315-319.

Lindberg A, Greisman S, Svenson S: Induction of endotoxin tolerance with nonpyrogenic $\mathrm{O}$-antigenic oligosaccharide protein conjugates. Infec. Immun. 1983, 41, 888-895.

MacGreggor RR: Granulocyte adherence changes induced by hemodialysis, endotoxin, epinephrine, and glucocorticoids. Ann. int. Med. 1977, 86, 35-39.

Milton AS: Prostaglandins and fever. Trends in pharmacological sciences 1982, 3, 490-492.

Morrison DC, Ryan $J L$ : Endotoxins and disease mechanisms. Ann. Rev. Med. 1987, 38, 417432.

Skarnes R, Brown K, Hull SS, McCracken JA: Role of prostaglandin $E$ in the biphasic fever response to endotoxin. J. exp. Med. 1981, 154, 1212-1224.

Tejedor $R$, Nelson $S$, Astry $C$, Summer $W$ : Contrasting effects of acute and chronic endotoxin against Pseudomonas aeruginosa (abstract). Clin. Res. 1986, 34, 228A.

Yagoda C, Bylund-Fellenius AC, Kindahl H: Clinical and endocrine response to repeated daily administration of endotoxin in pigs. Acta vet. scand. 1988, 29, 267-269.

Yagoda C, Bylund-Fellenius AC, Adner N, Kindahl $H$ : Biological responses of sheep treated with endotoxin-contaminated superoxide dis- mutase and endotoxin preparations. Acta vet. scand. 1990, 31, 207-217.

Zuckerman KS, Quesenberry PJ, Levin T, Sulli van $R$ : Contamination of erythropoietin by endotoxin: in vivo and in vitro effects on murine erythropoiesis. Blood 1979, 54, 146158.

\section{Sammanfattning \\ Några effekter av endotoxiner från Gram- negativa bakterier och deras betydelse som kontaminator av biologiska preparationer.} Syftet med denna studie var att skapa en modell som kunde användas till att undersöka det biologiska svaret för Salmonella typhimurium endotoxin i både sövda och vakna kaniner, och sedan jämföra detta svar med kaniner som injicerades med en endotoxin-kontaminerad biologisk preparation. Parametrarna som användes till att utvärdera det biologiska svaret inkluderade totalantalet leukocyter och differentialräkning, 15-ketodihydro$\mathrm{PGF}_{2 \alpha}$-mönster och kroppstemperatur.

Vakna grupper av kaniner erhöll 1000, 100, 10 eller $1 \mathrm{ng} / \mathrm{kg}$ av endotoxin via intravenös injektion; den sövda gruppen av kaniner erhöll 100 $\mathrm{ng} / \mathrm{kg}$ endotoxin (narkosen inducerades med Hypnorm ). Vidare, grupper av kaniner behandlades med Pharmacia-Chiron's 'recombinant human $\mathrm{Cu} / \mathrm{Zn}$ superoxide dismutase' (SOD) $(10 \mathrm{mg} / \mathrm{kg}$ kroppsvikt $=1.6$ endotoxin units $(\mathrm{EU}) / \mathrm{kg}$ ) eller Grünenthal's bovina SOD (två doser: $10 \mathrm{mg} / \mathrm{kg}=$ $400 \mathrm{EU} / \mathrm{kg}$, eller $50 \mathrm{mg} / \mathrm{kg}=2000 \mathrm{EU} / \mathrm{kg}$ ).

Resultaten visade att kaniner som erhöll endotoxin-kontaminerade preparationer uppvisar många av de vanliga tecknen på endotoxinemi, såsom leukopeni, högre prostaglandinmetabolitnivåer och ökad kroppstemperatur. Det finns en klar dosanknytning: högre doser av endotoxin ger en större förändring i alla parametrar medan de lägre doserna av endotoxin (10 och $1 \mathrm{ng} / \mathrm{kg}$ ) och $\mathrm{r}$-hSOD $(10 \mathrm{mg} / \mathrm{kg})$ ger t. ex. ingen leukopeni. Emellertid, inträffar en förändring i leukocytpopulationen så att polymorfkärniga leukocyter ökar och monocyter minskar. Dessa fynd visar att användningen av denna eller andra endotoxin-kontaminerade biologiska preparationer i djurförsök kan producera opålitliga resultat.

(Received September 11, 1989; accepted September 27, 1989).

Reprints may be requested from: Hans Kindahl, Department of Obstetrics and Gynaecology,

Swedish University of Agricultural Sciences, Box 7039, S-750 07, Uppsala, Sweden. 